\title{
Assessment of Drought Tolerant and High Yielding Groundnut Varieties in Ariyalur District, India
}

\author{
M. Saravanan*, A. Rajkala and G. Alagukannan \\ ICAR-Krishi Vigyan Kendra (Hosted By CREED), Cholamadevi, \\ Ariyalur - 612 902, Tamil Nadu, India \\ *Corresponding author
}

\begin{tabular}{|l|}
\hline Ke y w o r d s \\
$\begin{array}{l}\text { Groundnut, Pod } \\
\text { yield, Rain fed, } \\
\text { Root rot }\end{array}$ \\
\hline Article Info \\
\hline $\begin{array}{l}\text { Accepted: } \\
\text { 26 April } 2018 \\
\text { Available Online: } \\
\text { 10 May } 2018\end{array}$ \\
\hline
\end{tabular}

A B S T R A C T
Groundnut (Arachis hypogaea L.) is an important oil seed crop mainly grown under rainfed situation. Due to erratic rainfall and frequent drought during the crop growth period, groundnut yields are generally low and unstable under rainfed conditions. Drought during critical crop growth stages is crucial for yield in groundnut varieties. But tolerant genotypes may give better yield due to maintenance of physiological responses that were triggered during drought. On Farm Trials was conducted by Krishi Vigyan Kendra, Ariyalur to assess suitable drought tolerant and high yielding groundnut variety in terms of yield, acceptability and adoption potential during Kharif 2016-17 in Ariyalur district. The study revealed that CO 7 recorded higher pod yield $(1880 \mathrm{~kg} / \mathrm{ha})$, higher number of pods/plant (28.4), lesser root rot incidence (1.4\%), leaf spot incidence(26.0) and optimum plant population $\left(29.1\right.$ plants $\left./ \mathrm{m}^{2}\right)$ as compared to others. A maintain optimum plant population and reduction in root rot incidence was observed in CO 7 and Kadiri 9 as compared to check variety. Gross and net returns were Rs.1, 05,567/- and Rs.64, 988/-ha, respectively by cultivating CO 7 as against Rs.76,183/- and Rs.33,484/-ha in the check variety. CO 7, kadiri 9 and GJG 9 would be a better option for rainfed cultivation in Ariyalur district.

\section{Introduction}

Groundnut, the king of oil seeds is one of the important legume crops cultivated predominantly under rain-fed conditions in the tropical and semi-arid tropical countries including India, where it provides a major source of oil, carbohydrates and proteins (Bhauso et al., 2014). The seed is used mainly for edible oil and contains nearly half of the essential vitamins and one-third of the essential minerals. Hence, groundnut played an important role in nutritional security to the resource poor farmers. In addition, the haulms provided excellent fodder for livestock, cake obtained after oil extraction was used in animal feed and overall the crop acted as good source of biological nitrogen fixation (Nautiyal et al., 2011).

Groundnut is the sixth most important oilseed crop in the world. It contains $48-50 \%$ of oil and $26-28 \%$ of protein, and is a rich source of dietary fiber, minerals and vitamins. Globally, the crop is raised in 26.4 million hectares with a total production of 37.1 million MT. The 
average productivity is $1400 \mathrm{~kg} / \mathrm{ha}$. India shares 22 per cent of the world production (area 4.9 m.ha, production 5.8 MT). The area under rainfed groundnut in Tamil Nadu is 4.4 lakh hectares with a production of 9.11 lakh tones during Kharif 2016-17.

Drought is the major environmental factor contributing to the reduced agricultural productivity and food safety worldwide. Severity of drought depends on the stage of crop development, the duration of stress period and the magnitude of drought. Hence, the study was planned with the objectives to evaluate the improved groundnut varieties with high yield and drought tolerance under kharif season through on farm trials in Ariyalur district.

\section{Materials and Methods}

Conduct of On-Farm Trial (OFT) is the foremost man date of Krishi Vigyan Kendra across India to assess the technology under particular agro ecosystem or at district level. On-farm trials are being conducted on farmers' participatory mode during kharif 2017 with seven farmers from Kasankottai village in T.Palur block of Ariyalur district. Sowing was performed under rainfed condition, depending on the onset of monsoon, sowing was completed within the first week of July in the all fields. The soil was sandy clay loam in texture with $\mathrm{pH}$ 7.0. The fertility status of the soil was low, medium and high in the available $\mathrm{N}, \mathrm{P}_{2} \mathrm{O}_{5}$, and $\mathrm{K}_{2} \mathrm{O}$, the values are 168,25 and $420 \mathrm{~kg} \mathrm{ha}^{-1}$ respectively. The farmers were sowing the country plough behind the manual sowing practice. The experiment was laid out in a randomized block design (RBD) with three replications. Four improved groundnut varieties viz. CO 7, Kadiri 9, GJG 9, VRI 2 (Table 1) and check variety in the trial were taken for study. The recommended package of practices for groundnut cultivation followed as per TNAU recommendations. The data on germination per cent, plant population, physiological parameters, No. of pods/ plant, pod yield, haulm yield and economics of all the varieties were recorded.

Observations on growth characters such as plant height, leaf area index and dry matter production were recorded at 40,80 DAS and at harvest from five randomly selected plants in each plot. The samples were collected from sampling rows in each plot for dry matter production and were used for the estimation of DMP. The data obtained from experiments were subjected to statistical analysis by using the statistical software AGRES.

\section{Crop Growth Rate (CGR)}

The mean CGR was calculated as suggested by Watson (1958) using the formula

$\operatorname{CGR}\left(\mathrm{g} \mathrm{m}^{-2}\right.$ day $)=\frac{\mathrm{W}_{2}-\mathrm{W}_{1}}{\left.---\mathrm{t}_{2}-\mathrm{t}_{1}\right)}$

Where, $\mathrm{W}_{1}$ and $\mathrm{W}_{2}$ were the dry weight of plants in $g$ at times $t_{1}$ and $t_{2}$ respectively.

\section{Leaf Area Index (LAI)}

LAI was calculated using the following formula as suggested by Ashley et al., (1963).

$$
\text { LAI }=\frac{\text { Leaf area }}{\text { Land area }\left(\mathrm{cm}^{2}\right) \text { occupied by one plant }}
$$

\section{Relative leaf water content}

Relative leaf water content was estimated as suggested by Barrs and Weatherley (1962). Fully expanded third leaf of comparable age and orientation at the top was collected before irrigation cycles. Two gram (fresh weight) was weighed from the leaf discs and was 
floated in distilled water for four hours; then surface dried using tissue paper and weighed (leaf turgid weight). The dry weight was obtained by drying leaf discs in an oven at 65 $\pm 5^{0} \mathrm{C}$ which is sufficiently long to dry the discs to constant weight.

The RLWC was calculated from the formula given below

$$
\begin{array}{r}
\text { Fresh weight }(\mathrm{g})-\text { Dry weight }(\mathrm{g}) \\
\operatorname{RLWC}(\%)=\text {--- } \\
\text { Turgid weight }(\mathrm{g})-\text { Dry weight }(\mathrm{g})
\end{array}
$$

\section{Chlorophyll content}

Chlorophyll content of leaves was determined as per the method of Arnon (1949). The leaf tissues were extracted in $80 \%$ acetone. The absorbance was read at $663 \mathrm{~nm}$ and $645 \mathrm{~nm}$ on spectrophotometer. The chlorophyll content was calculated (mg of chlorophyll per $\mathrm{g}$ of tissue) using formula, mg of total chlorophyll $=20.2(\mathrm{~A} \mathrm{645})+8.02(\mathrm{~A} 663) \times \mathrm{V} / 1000 \mathrm{x}$ weight of sample.

\section{Proline content}

Proline content was estimated as per the method described by Bates et al., (1973) and expressed as $\mu$ mole per $\mathrm{g}$ FW by measuring absorbance at $520 \mathrm{~nm}$ with toluene as blank.

\section{Results and Discussion}

\section{Growth parameters}

With regard to evaluation of groundnut varieties significant difference were observed on plant height at 80 DAS and at harvest stage, Co 7 recorded the highest value for plant height of $38.5 \mathrm{~cm}$ and $44.5 \mathrm{~cm}$ at 80 DAS and at harvest stages, respectively (Table 2). It was least in farmer practice at $80 \mathrm{DAS}$ and at harvest. Higher plant height in $\mathrm{CO} 7$ may be attributed to the variety which tends to germinate and establish early compared to farmer practice varieties with medium and small seeds. Similar increase in plant height with large seeds was also observed by Singh et al., (1998) and Nandania et al., (1992). Mensah and Okpere (2000) showed the significant differences among the different varieties of groundnut for plant height throughout the growth period.

\section{Physiological parameters}

The pattern of dry matter production and its distribution into component plant parts has been of phenomenal interest to the research workers engaged in yield analysis. In the present investigation, it envisaged to know the pattern of dry matter accumulation, its distribution in component parts of plant (Table 3). The variety, CO 7 (3961 kg/ha) maintained the highest dry matter production as an account of higher magnitude of dry matter in leaves, stem and roots. In addition, Kadiri 7 and GJG 9 were also recorded highest dry matter production of $3745 \mathrm{~kg} / \mathrm{ha}$ and 3395 $\mathrm{kg} / \mathrm{ha}$ respectively.

Among varieties (CO7) recorded higher relative leaf water content (RLWC) of 68.5 at flowering stage. The lowest relative leaf water content was recorded in farmer's practice. The highest reduction was recorded in farmer practice (47.4 per cent). Bars and Weatherley (1968) suggested that RWC under stress condition could be used as measure of tolerance to stress. Decline of RWC under drought stress was observed earlier in groundnut by Sharda and Naik (2011). This might be due to reduction in water availability, stomata opening and closing is more affected. Similar results have been reported in groundnut (Madhusudhan and Sudhakar, 2014), in horsegram (Bhardwaj and Yadav, 2012) and in pigeonpea (Kumar et al., 2011). The results obtained in the present study are in agreement with these reports. 
Table. 2 Growth performance on groundnut varieties in farmer's field (Average of five trials)

\begin{tabular}{|c|c|c|c|c|c|c|c|c|c|c|c|c|c|c|}
\hline \multirow[t]{2}{*}{ Variety } & \multicolumn{4}{|c|}{40 DAS } & \multicolumn{5}{|c|}{80 DAS } & \multicolumn{5}{|c|}{ At harvest(110 DAS) } \\
\hline & $\begin{array}{l}\text { Germination } \\
\text { percentage } \\
(\%)\end{array}$ & $\begin{array}{l}\text { Plant } \\
\text { height } \\
\text { (cm) }\end{array}$ & $\begin{array}{l}\text { DMP } \\
\text { (kg/ha) }\end{array}$ & LAI & $\begin{array}{l}\text { Plant } \\
\text { populatio } \\
\text { n/m } \mathbf{m}^{2}\end{array}$ & $\begin{array}{l}\text { Plant } \\
\text { height } \\
(\mathrm{cm})\end{array}$ & $\begin{array}{l}\text { DMP } \\
\text { (kg/ha) }\end{array}$ & LAI & $\begin{array}{l}\text { CGR } \\
\left(\mathrm{gm}^{-2}\right. \\
\text { day })\end{array}$ & $\begin{array}{l}\text { Plant } \\
\text { populati } \\
\text { on } / \mathrm{m}^{2}\end{array}$ & $\begin{array}{l}\text { Plant } \\
\text { height } \\
(\mathrm{cm})\end{array}$ & $\begin{array}{l}\text { DMP } \\
\text { (kg/ha) }\end{array}$ & LAI & $\begin{array}{l}\text { CGR } \\
\left(\mathrm{gm}^{-2}\right. \\
\text { day })\end{array}$ \\
\hline $\begin{array}{l}\text { Farmer's } \\
\text { practice }\end{array}$ & 73.5 & 11.5 & 1865 & 1.65 & 17 & 27.5 & 2985 & 2.15 & 28.0 & 15.12 & 30.2 & 3109 & 2.05 & 4.13 \\
\hline $\mathrm{CO} 7$ & 91.0 & 10.5 & 1835 & 1.54 & 26 & 38.5 & 3961 & 3.20 & 53.2 & 26.25 & 44.5 & 4250 & 2.90 & 9.63 \\
\hline Kadiri 9 & 91.2 & 11.0 & 1900 & 1.77 & 23 & 33.7 & 3745 & 2.95 & 46.1 & 23.20 & 38.2 & 3910 & 2.45 & 5.50 \\
\hline VRI 2 & 85.5 & 10.9 & 1840 & 1.59 & 19 & 29.0 & 3356 & 2.35 & 37.9 & 18.50 & 34.5 & 3565 & 2.10 & 6.97 \\
\hline GJG 9 & 89.9 & 10.7 & 1845 & 1.66 & 20 & 32.5 & 3395 & 2.64 & 38.7 & 19.61 & 36.9 & 3620 & 2.35 & 7.50 \\
\hline SEd & 4.09 & 0.51 & 87.4 & 0.07 & 1.03 & 1.55 & 168 & 0.13 & 2.04 & 1.01 & 1.77 & 177 & 0.11 & 0.33 \\
\hline $\begin{array}{l}\mathrm{CD} \\
(P=0.05)\end{array}$ & 8.68 & NS & NS & NS & 2.18 & 3.30 & 356 & 0.27 & 4.33 & 2.10 & 3.76 & 377 & 0.24 & 0.69 \\
\hline
\end{tabular}

Table.3 Chlorophyll, RWC and proline content in groundnut leaves during water stress

\begin{tabular}{|l|c|c|c|}
\hline Variety & $\begin{array}{c}\text { Chlorophyll } \\
\text { (mg/g fr.wt.) }\end{array}$ & $\begin{array}{c}\text { Relative water } \\
\text { content }(\%)\end{array}$ & $\begin{array}{c}\text { Proline } \\
\text { (umoles/g fr.wt.) }\end{array}$ \\
\hline Farmer's practice & 1.25 & 47.5 & 17.2 \\
\hline CO 7 & 1.91 & 68.5 & 24.3 \\
\hline Kadiri 9 & 1.81 & 51.5 & 21.6 \\
\hline VRI 2 & 1.55 & 49.8 & 20.9 \\
\hline GJG 9 & 1.45 & 53.8 & 21.8 \\
\hline SEd & $\mathbf{0 . 0 8}$ & $\mathbf{2 . 5 9}$ & $\mathbf{1 . 0 4}$ \\
\hline CD(P = 0.05) & $\mathbf{0 . 1 7}$ & $\mathbf{5 . 4 9}$ & $\mathbf{2 . 1 4}$ \\
\hline
\end{tabular}


Table.4 Disease incidence as influenced by groundnut genotypes

\begin{tabular}{|l|c|c|}
\hline Variety & $\begin{array}{c}\text { \% of root rot } \\
\text { incidence }\end{array}$ & $\begin{array}{c}\% \text { of leaf spot } \\
\text { incidence }\end{array}$ \\
\hline Farmer's practice & 6.2 & 29.6 \\
\hline CO 7 & 1.2 & 24.0 \\
\hline Kadiri 9 & 1.2 & 26.2 \\
\hline VRJ 2 & 4.6 & 27.5 \\
\hline GJG 9 & 2.6 & 25.2 \\
\hline SEd & $\mathbf{0 . 2}$ & $\mathbf{1 . 2}$ \\
\hline CD (P = 0.05) & $\mathbf{0 . 4}$ & $\mathbf{2 . 6}$ \\
\hline
\end{tabular}

Table.5 Yield and yield contributing characters as influenced by groundnut genotypes

\begin{tabular}{|l|c|c|c|c|c|c|c|c|} 
& $\begin{array}{l}\text { No. Of } \\
\text { pods/plant }\end{array}$ & Yield (kg/ha) & $\begin{array}{c}\text { Haulm yield } \\
\text { (kg/ha) }\end{array}$ & $\begin{array}{c}\text { Oil content } \\
(\%)\end{array}$ & $\begin{array}{c}\text { Cost of } \\
\text { Cultivation } \\
\text { (Rs./ha) }\end{array}$ & $\begin{array}{c}\text { Gross } \\
\text { Return } \\
\text { (Rs./ha) }\end{array}$ & $\begin{array}{c}\text { Net } \\
\text { Income } \\
(\text { Rs./ha) }\end{array}$ \\
\hline Farmer \\
practices
\end{tabular}


Table.1 Characteristics of varieties selected for on-farm trial

\begin{tabular}{|r|l|c|c|c|c|c|}
\hline $\begin{array}{l}\text { S. } \\
\text { No }\end{array}$ & Variety & Source & $\begin{array}{l}\text { Duration } \\
\text { (days) }\end{array}$ & $\begin{array}{l}\text { Shelling } \\
\text { percentage }\end{array}$ & $\begin{array}{l}\text { Oil } \\
\text { content }\end{array}$ & $\begin{array}{l}\text { Potential } \\
\text { yield (kg/ha) }\end{array}$ \\
\hline $\mathbf{1}$ & $\begin{array}{l}\text { Farmer practice } \\
\text { variety }\end{array}$ & - & $110-120$ & 71 & 48 & 1500 \\
\hline $\mathbf{2}$ & Kadiri 9 & ANGRAU, 2009 & $110-120$ & 75 & 49 & 2100 \\
\hline $\mathbf{3}$ & Co 7 & TNAU, 2013 & $105-110$ & 75 & 51 & 2300 \\
\hline $\mathbf{4}$ & VRI 2 & TNAU, 1989 & $105-110$ & 75 & 50 & 1790 \\
\hline $\mathbf{5}$ & GJG 9 & JAU, 2009 & $110-120$ & 73 & 48 & 1750 \\
\hline
\end{tabular}

The chlorophyll content also decreased significantly under stressed condition in all genotypes of groundnut. Chlorophyll content of water stressed plants it was found to be decreased from 1.25 to $1.9 \mathrm{mg} / \mathrm{g}$ (Table 3). The minimum decrease of 1.91 was observed in $\mathrm{CO} 7$ while unknown farmers variety recorded higher decline of 1.25 (Table 3). It has been reported that the loss of chlorophyll under water stress is due to inactivation of photosynthesis (Kumar et al., 2011), furthermore, stress induced reduction is ascribed to loss of chloroplast membrane integrity due to lipid peroxidation (Manivannan et al., 2007). The decrease of photosynthetic pigment under water limitation has been considered a typical symptom of oxidative stress and may be result of pigment photo-oxidation and chlorophyll degradation and prevent its biosynthesis have been reported in peanut (Farooq et al., 2009; Sharada and Naik 2011; Kumar et al., 2011; Madhusudhan and Sudhakar, 2014)

Plants accumulate osmolytes through biochemical mechanisms such as proline which improve their ability to withstand stress. Imposing water stress resulted more than 50 per cent increase proline content i.e. 17.2 to $24.3 \mu$ mol per $\mathrm{g}$ fr. wt (Table 3). The highest proline accumulated in CO 7, GJG 9 and Kadiri 9 respectively. In terms of percent increase over control the maximum per cent increase was observed in genotype $\mathrm{CO} 7$ followed by, GJG 9 and Kadiri 9 and the least in farmer practice. In present investigation higher concentration of proline indicate an efficient mechanism for osmotic regulation, stabilization of cellular structure and adaption to water stress which is in agreement with the earlier reports (Gunes et al., 2008; Solanki and Sarangi, 2014). It is also associated with lower levels of RWC. Our results of proline accumulation are in agreement with the results of reported in groundnut (Madhusudhan and Sudhakar, 2014), in horse gram (Bhardwaj and Yadav, 2012) and in chickpea (Kumar et al., 2006; Mafakheri et al., 2011).

\section{Yield and economics}

On-farm trials revealed that groundnut variety CO 7 recorded higher pod yield $(1880 \mathrm{~kg} / \mathrm{ha})$, higher number of pods/plant (28.4), lesser root rot incidence $(1.4 \%)$ and optimum plant population $\left(25.1\right.$ plants $\left./ \mathrm{m}^{2}\right)$ as compared to Kadiri 9 and farmer practice variety (Table 5). Groundnut varieties, CO 7 and Kadiri 9 recorded 27.9 and 16.3 per cent higher pod yield than check variety, respectively. With regard to haulm yield, $\mathrm{CO} 7$ variety recorded highest haulm yield of $4335 \mathrm{~kg} / \mathrm{ha}$ as compared to other varieties.

Gross and net returns were Rs.1, 05,567/- and Rs.64,988/- ha, respectively by cultivating CO 7 as against Rs.76,183/- and Rs.33,484/ha in the farmers variety. The probable reason were drought withstand genotype and lesser 
incidence of root rot disease coupled with higher number of pods/plant resulting higher pod and haulm yield, these results were in agreement with the findings of Vindhiyavarman et al., (2010) (Table 4).

Groundnut variety, CO 7 recorded more number of pods per plant, less incidence of root rot disease, higher pod yield, good withstand under drought and performed very well compared to Kadiri 9, GJG 9 and farmer practice variety under rainfed condition. Farmers were very satisfied with $\mathrm{CO} 7$, as the crop did not suffer from a dry spell of 17-21 days without rain. So, groundnut variety $\mathrm{CO} 7$ would be better option for rainfed cultivation during kharif season in Ariyalur district.

\section{References}

Arnon, D.I. (1949). Copper enzyme in isolated chloroplasts. Polyphenol oxidase in Beta

Ashley, D. A., Doss, B.D. and Bennett, O.L. 1963. A method for determining leaf area in cotton. Agron. J., 55: 584-585.

Barrs, H.D. and Weatherley, P.E. 1962. A reexamination of the relative turgidity technique for estimating deficit in leaves. Aust. J. Biol. Sci., 15: 413-428.

Bates, L.S., Waldren, R.P. and Teare, I.D. (1973). Rapid determination of free proline of over expression of bacterial $m t l D$ gene in peanut improves drought tolerance through accumulation of mannitol. Scientific World J. 2014: 125967. doi:10.1155/2014/125967

Bhardwaj, J. and Yadav, S.K. (2012). Comparative study on biochemical parameters and antioxidant enzymes in a drought tolerant and a sensitive variety of horsegram (Macrotyloma uniflorum) under drought stress. Am. $J$. Plant Physiol., 7: 17-29.
Bhauso, T.D., Radhakrishnan, T., Kumar, A., Mishra, G.P., Dobaria, J.R., Patel, K.K., et al., (2014b).

Farooq, M., Wahid, A., Kobayashi, N., Fujita, D. and Basra, S.M.A. (2009). Plant drought stress: effects, mechanisms and management. Agron. Sustain. Dev., 29: 185-212.

Ghosh, P.K., Mathur, R.K., Ravindra, V. and Gor, H.K. Dry matter accumulation, nitrogen uptake and their partitioning pattern in virginia groundnut (Arachis hypogaea L.). Indian J. Pl. Physiol. 2 (3): 234-236 (1997).

Gunes A., Pilbeam D., Inal A., Coban S. (2008). Influence of silicon on sunflower cultivars under drought stress, I: Growth, antioxidant mechanisms and lipid peroxidation. Commun. Soil Sci. Plant Nutr., 39: 1885-1903.

Kumar, R.R., Karajol, K. and Naik, G.R. (2011). Effect of polyethylene glycol induced water stress on physiological and biochemical response in pigeonpea Plant Physiol. 3:1487-152.

Madhusudhan, K.V. and Sudhakar, C. (2014). Alteration in proline metabolism in groundnut (Arachis Hypogae L.) under soil water deficits. Int. J. Sci. Rea. 3: 3.

Manivannan, P., Jaleel, C.A., Sankar, B., Kishorekumar, A., Somasundaram, R., Alagu Lakshmanan, G.M. and Panneerselvam, R. (2007). Growth, biochemical modifications and proline metabolism in Helianthus annuus L. as induced by drought stress. Colloids Surf. B: Biointerf, 59: 141-149

Mensah. J. K. and V. E. Okpere 2000. Screening of Four Groundnut Cultivars from Nigeria for drought resistant. Legume Res. 23(1): 37-41.

Nandania, V.A., Modhawadia, M.M., Patel, J.C., Sadaria, S.G. and Patel, B.S., 1992, Response of rainy season bunch groundnut (Arachis hypogaea L.) to row 
spacing and seed rate. Indian $J$. Agron., 37(3):597-599.

Nautiyal P C, Zala P V, Tomar R K, Sodayadiya P and Tavethia B (2011). Evaluation of water use efficiency newly developed varieties of groundnut in on-farm trials in two different rainfall areas in Gujarat, India. SAT eJournal / eJournal.icrisat.org (9):1-6.

Sharada, P. and Naik, G.R. (2011). Physiological and biochemical response of groundnut genotypes to drought stress. World J. Sci.Tech. 11: 60-66.

Sharada, P. and Naik, G.R. (2011). Physiological and biochemical response of groundnut genotypes to drought stress. World J. Sci.Tech. 11: 60-66.

Singh, P., Thakur, D., Vaish, C. P., Katiyar, R. P. and Gupta, P.K., 1998, Studies on packing materials for storage of soybean seeds under ambient conditions. Seed Tech. News, 28(4): 75.

Solanki, J.K. and Sarngi, S.K. (2014). Effect of drought stress on proline accumulation in peanut genotypes. International Journal of Advanced Research. 2 (10): 301-309.

Vindhiyavarman P, Manivannan N, Nigam S $\mathrm{N}$ and Muralidharan V (2010). Farmers' Participatory Varietal Selection in Groundnut: A Case Study from Tamil Nadu, India. Electronic Journal of Plant Breeding 1(4):878- 881.

Watson, D.F. 1958. The dependence of Net assimilation rate on Leaf area index. Ann. Bot., 10: 41-71.

\section{How to cite this article:}

Saravanan, M., A. Rajkala and Alagukannan, G. 2018. Assessment of Drought Tolerant and High Yielding Groundnut Varieties in Ariyalur District, India. Int.J.Curr.Microbiol.App.Sci. 7(05): 3492-3499. doi: https://doi.org/10.20546/ijcmas.2018.705.403 